\title{
RECENZE
}

Kryštof Boháček:

\section{Mnohost hlasů Platónovy rétoriky: jedna řeč pro filosofii i sofistiku}

Recenzovaná monografie: McCoy, M., 2008, Plato on the Rhetoric of Philosophers and

\author{
Sophists, New York.
}

Kniha Mariny McCoy se systematickým způsobem zabývá v Čechách nepříliš sledovanou problematikou platónské rétoriky. Autorku lze zařadit do proudu zejména amerických myslitelů, navazujících na tzv. rhetorical turn; po metodické stránce je východiskem knihy rétorická analýza Apologie Sókrata, Prótagorás, Gorgiás, Ústava, Sofistés a Faidros.

V úvodu autorka shrnuje dosažené výsledky bádání na poli antické rétoriky za poslední čtvrtstoletí, zejména s důrazem na problematiku sofistů, vztahu mezi rétorikou a filosofií a Platónovým řešením těchto otázek. Již prostř̌ednictvím samotné této rekapitulace autorka problematizuje několik zažitých klišé platónského bádání a tvrdí, že pro samého Platóna bylo obtížné přesně stanovit distinkci mezi filosofem a sofistou, nebot' filosofie, tak jak jí Platón podle autorky chápe, vždy obsahuje podstatnou rétorickou dimenzi. V Platónově díle je tedy třeba spíše hledat rozdíl mezi sofistickou rétorikou a filosofickou rétorikou, jinými slovy zaměřit se vlastně na rozporuplný vztah filosofie a sofistiky. Hlavním vodítkem není podle autorky u Platóna nikdy technická či odborná kvalifikace (nebot', jak se ukazuje, znalosti i kompetence filosofa a sofisty jsou v drtivé části sledovatelných textových výskytů identické nebo přinejmenším nerozlišitelné), ale vždy morální kvalita duše konkrétního myslitele.

Svá tvrzení dokládá Marina McCoy nejprve na rozboru Apologie, jejíž mnohé prvky nachází rovněž v jiných dobových spisech autorů jako Antifón, Lysiás či Démosthenés, kteří rovněž formálně vycházejí z modelu soudní obhajoby, avšak záběr díla významně přesahuje obzor konkrétní pře. Daleko závažnější je podle autorky vazba na Gorgiovu Apologii Palaméda, která výrazně přesahuje pouhou shodu ve využitých topoi. Obě díla mají obdobnou strukturu argumentace, v zásadě se jedná o stejný druh obhajoby před př́mo neprokazatelným a proto též nevyvratitelným nařčením z hrdelního zločinu pomocí tzv. eikota, a především se sám Sókratés v samém závěru své řeči explicitně přirovnává 
k Palamédovi. Marina McCoy odmítá tuto narážku jako doklad vrcholné parodie Gorgiova spisu a poukazuje na to, že Gorgiova rétorika byla natolik vlivná, že by pokus o její úplné zesměšnění Platónovi nepomohl: podle autorky si musíme vždy klást právnickou/rétorickou otázku cui bono! Platónovi jde o to, aby obhájil svého učitele z nařčení, ale zároveň toto nařčení nesmí být podle autorky prokázáno jako zcela absurdní. Aristotanova Oblaka nám totiž dokládají, že mnozí vlivní intelektuálové se se zněním žaloby ztotožňovali a její přespř́ilišné zlehčení by nevyznívalo věrohodně; navíc neustále hrozilo, že se athénský čtenář urazí, pokud jeho názor bude šmahem odmítnut.

Autorka se proto domnívá, že Platón naopak ukazuje, že Sókratés má opravdu mnoho společného se sofisty, přesněji že vlastně sofista opravdu je - že je však zároveň mnohem více, než pouhým sofistou! Jinými slovy že využívá sofistiky k cílům, které jsou navýsost chvályhodné a morálně obhajitelné. Tento rozdíl poté autorka precizuje na pasážích z Prótagory, v nichž slavný sofista $\mathrm{z}$ hlediska dnešních kritérií vyhovuje představám o filosofii. Na rozdíl od Sókrata ovšem zcela ignoruje důležitou schopnost naslouchat, což z něj nakonec dělá přece jen myslitelskou zkamenělinu. Sókratés naproti tomu ukazuje, že filosofie která obstojí nutně musí obsahovat takové rétorické kvality jako vnímavost k situaci a schopnost naslouchat tomu podstatnému $\mathrm{v}$ řeči partnera.

Velmi odvážně přistoupila Marina McCoy k výkladu dialogu Gorgiás, v němž postupně zpochybňuje všechna známá výkladová schémata: výsledek rozhovoru mezi Gorgiou a Sókratem je podle ní nejistý a spíše mluví v neprospěch Sókrata, který zjevně postupuje podle Gorgiova výměru rétoriky. Rozhovor s Pólem dle autorky zase přináší téma „Zdravého selského rozumu“ či „,vrozeného/přirozeného pohledu“, který pro Póla představuje ultima ratio i v porovnání s konsistencí jakékoli argumentace: Sókratés je ochoten přijmout i závěry, které se z hlediska naší životní perspektivy jeví jako atopa. Na tuto problematiku pak navazuje rozhovor s Kallikleem, jenž ji významně prohlubuje paralelou s Eurípidovou Antiopé, v níž rovněž sledujeme konflikt mezi teoretikem-intelektuálem a mužem obchodnicko-politické praxe. Závěr je podle autorky v obou př́padech stejný, mezi oběma světy není nalezen spojovací můstek a zachovávají si odděleně konstituované diskursy. Závěrečný deus ex machina (v dialogu jeho roli supluje posmrtný mýtus) může být pouze morálním apelem, nikoli argumentem.

Ústava přináší podle Mariny McCoy jasnou tezi: rozdíl mezi filosofem a sofistou spočívá v kvalitě jejich touhy. Filosof touží po formách a tedy je morálně nadřazen sofistovi, proto je jeho rétorika oprávněná, i když vlastně činí totéž, co sofistova, totiž mámí a po libosti 
vodí duše ostatních kam se jí zlíbí. Filosofu se totiž vždy zlíbí směr ku prospěchu zmámeného.

Tento model je poté konfrontován se suchou dialektikou elejského cizince v Sofistovi, jenž podle autorky nemůže představovat model pravé filosofie. Ignoruje totiž názor partnera a filosofii zaměňuje s hledáním definic. Tento cizincův deficit vynikne podle autorky obzvláště ve srovnání s Theaitétem, jenž se podle dramatického rámce obou dialogů odehrává o pouhý den dříve: po tom, co zaznělo $\mathrm{v}$ Theaitétovi, nelze podle autorky Platónův pohled v žádném př́ípadě hledat někde poblíž elejského cizince, ale spíše v intencích palinodie z Faidra. 